\title{
Erratum to: Reducing Aggression and Impulsivity Through School-Based Prevention Programs: A Gene by Intervention Interaction
}

Rashelle J. Musci • Catherine P. Bradshaw •

Brion Maher • George R. Uhl • Sheppard G. Kellam •

Nicholas S. Ialongo

Published online: 23 August 2014

(C) Society for Prevention Research 2014

Erratum to: Prev Sci

DOI 10.1007/s11121-013-0441-3

The original version of this article unfortunately contained a duplicate figure/graph in place of the correct graph (Fig. 1). The correct version of the figure is here.

The online version of the original article can be found at http://dx.doi.org/ 10.1007/s11121-013-0441-3 .

R. J. Musci $(\bowtie) \cdot$ C. P. Bradshaw · B. Maher · S. G. Kellam • N. S. Ialongo

Department of Mental Health, Johns Hopkins Bloomberg School of Public Health, Rm. 806, 624 N. Broadway, Hampton House 850t, Baltimore, MD 21205, USA

e-mail: rmusci@jhsph.edu

G. R. Uhl

Molecular Neurobiology Division, NIDA Intramural Research

Program, Baltimore, MD, USA
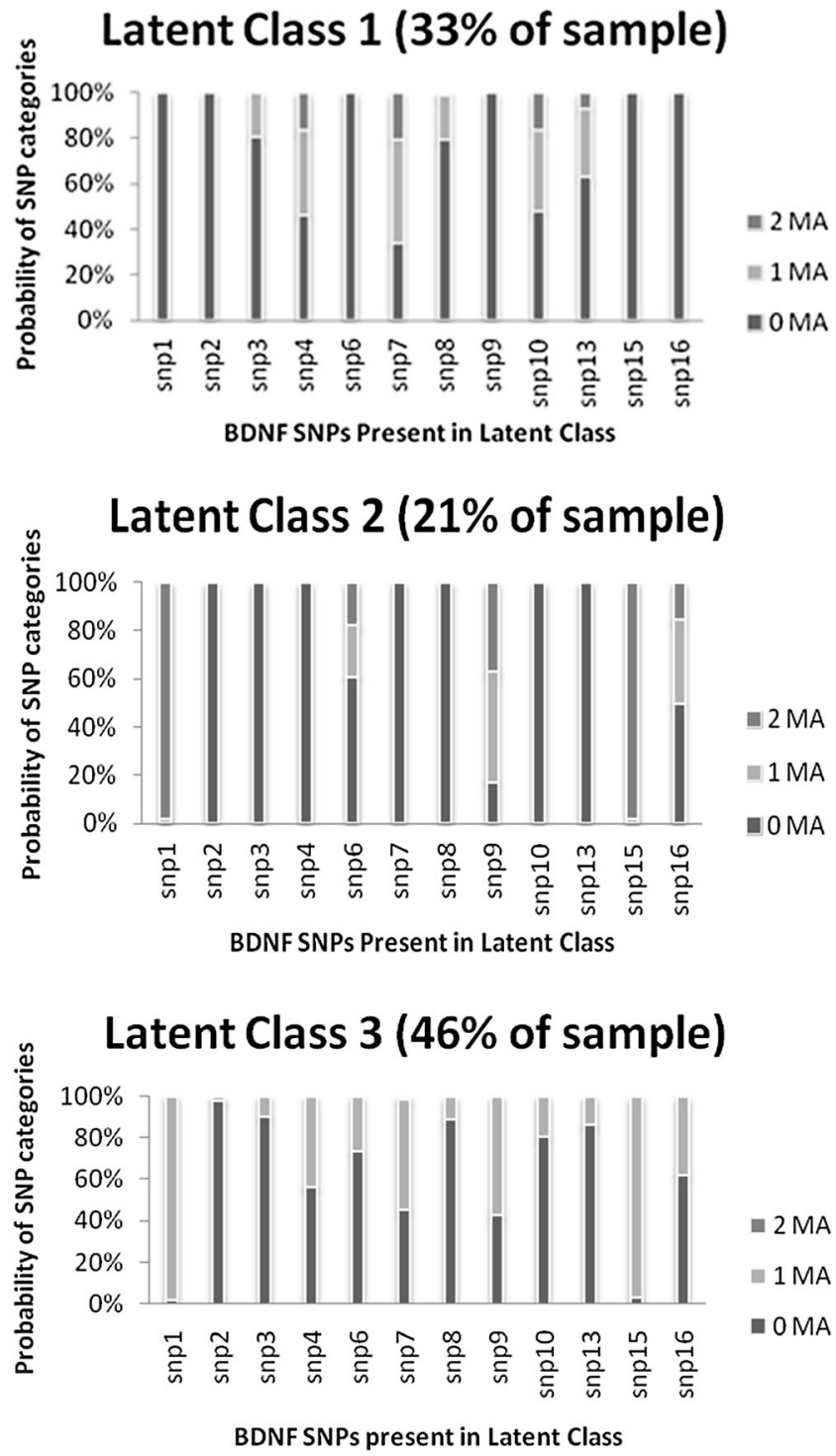

Fig. 1 Stacked bar plots of the SNP categories across the SNPs included as indicators in the BDNF latent class analysis 